\title{
Phosphorus transfer at a small catchment in southeastern Brazil: distributed modelling in different land use scenarios
}

\author{
Transferência de fósforo em uma bacia hidrográfica no sudeste brasileiro: \\ modelagem distribuída em diferentes cenários de uso do solo
}

\author{
Diêgo Faustolo Alves Bispo ${ }^{1 *}$, Marx Leandro Naves Silva ${ }^{1}$, João José Granate de Sá e Melo Marques ${ }^{1}$, \\ Marianne Bechmann², Pedro Velloso Gomes Batista', Nilton Curi'
}

\author{
'Universidade Federal de Lavras/UFLA, Departamento de Ciência do Solo/DCS, Lavras, MG, Brasil \\ ${ }^{2}$ Norwegian Institute for Bioeconomy Research/NIBIO, Norway \\ *Corresponding author: diegofaustolo@gmail.com \\ Received in April 23, 2017 and approved in July 4, 2017
}

\begin{abstract}
Identifying and ranking nutrient loss risk areas are important steps towards integrated catchment management. This study aimed to apply the P index model at the Posses catchment, south of the state of Minas Gerais, Brazil. We applied the P index for the current land use at the Posses catchment and for two hypothetical scenarios: scenario 1, in which P fertilizer was applied to all land uses, except for native forests; and scenario 2, which considered the use of P fertilizer as in scenario 1, and that the Environmental Protection Areas referring to the riparian forests and springs were totally restored. Considering current land use, almost the whole catchment area (91.4\%) displayed a low P loss risk. The highest P index was associated to croplands and eucalyptus plantations. Regarding scenario 1, areas under pasture fell into the low (15.1\%), medium (45.5\%), high (27.1\%) and very high (12.3\%) P index categories. Environmental Protection Areas on scenario 2 decreased the P loss risk from the scenario 1 in $37.6 \%$. Hence, the model outputs indicate that the reforestation of buffer zones can decrease $\mathrm{P}$ loss risk in the case increasing use of $\mathrm{P}$ fertilizer. The $\mathrm{P}$ index model is a potential support tool to promote judicious use of fertilizers and conservation practices at the Posses catchment.
\end{abstract}

Index terms: P index; nutrient loss; water erosion; land use management; environmental services.

\begin{abstract}
RESUMO
Identificar e classificar áreas quanto ao risco de perda de nutrientes são passos importantes para o manejo integrado de bacia hidrográfica. O objetivo deste estudo foi aplicar o modelo Índice P na bacia hidrográfica das Posses, Extrema-MG. O Índice P foi empregado sobre as condições atuais de uso da terra na bacia hidrográfica das Posses e na simulação de dois cenários: cenário 1, o fertilizante P foi aplicado para todos os usos, exceto para florestas nativas e, cenário 2, além do fertilizante P ser aplicado da mesma forma que no cenário 1 , considerou-se que as Áreas de Proteção Ambiental referentes as matas ciliares e nascentes fossem totalmente restituídas. Considerando o uso atual, quase toda a bacia hidrográfica $(91,4 \%)$ apresentou baixo risco de perda de P. O maior índice de P foi associado a lavouras e plantações de eucalipto. No cenário 1, as pastagem apresentaram Índice P baixo (15,1\%), médio (45,5\%), alto (27,1\%) e muito alto (12,3\%). No cenário 2, as Áreas de Proteção Ambiental promoveram uma redução de 37,6\% no risco de perda de P do cenário 1. Dessa forma, os resultados do modelo indicam que o reflorestamento de matas ciliares pode reduzir o risco de perdas de $\mathrm{P}$ no caso do aumento do uso de fertilizantes. O Índice P é uma potencial ferramenta para promoção do uso criterioso de fertilizantes e de práticas conservacionistas na bacia hidrográfica das Posses.
\end{abstract}

Termos para indexação: Índice P; perda de nutrientes; erosão hídrica; gestão do uso da terra; serviços ambientais.

\section{INTRODUCTION}

Nutrient transport from agricultural areas to water bodies has been regarded as one of the most serious environmental problems decreasing soil and water quality. Nutrient losses due to erosion deplete soil fertility. Also, nutrient-enriched sediments can contaminate water courses. This has led to several studies about nutrient losses involving erosion, mainly from non-point sources areas (Buchanan et al., 2013; Mardamootoo; Kwong;
Preez, 2013; Collins; Stutter; Kronvang, 2014; Ockenden et al., 2014; Zhou et al., 2015). Phosphorus has been highlighted in several studies because it is often the limiting element to eutrophication of freshwaters (Schindler, 1977; Sharpley et al., 2013; Campbell; Jordan; Arnscheidt, 2015; Dechen et al., 2015; Gatiboni et al., 2015; Cela et al., 2016; Lou et al., 2016; Roberts et al., 2017). Land use may strongly influence $\mathrm{P}$ transfers on catchments: higher rates of fertilizer application are expected on intensively 
cultivated croplands, as well as increased run-off and soil losses. On the other hand, reforestation of riparian zones may limit sediment delivery to water courses, which can help decrease $\mathrm{P}$ transfer.

Many detailed models have been developed to estimate P transfer (Beasley; Huggins; Monke, 1980; Williams; Jones; Dyke, 1984; Arnold et al., 1998; Gollamudi; Madramootoo; Enright, 2007), but there are also simpler tools, such as the P index model, which require much less input data and can be used at field and catchment scales (Bechmann; Stalnacke; Kvaerno, 2007). The $P$ index was first developed by Lemunyon and Gilbert (1993) to identify and rank vulnerable sites to $\mathrm{P}$ losses and to support management planning towards reducing $\mathrm{P}$ loss from a watershed. Other $\mathrm{P}$ index versions have subsequently been developed for different conditions of soil, climate, land use and management (Eghball; Gilley, 2001; Sharpley et al., 2003; Weld et al., 2003; NRCS, 2006; Bechmann; Stalnacke; Kvaerno, 2007; Ketterings et al., 2017). The main differences between these versions are related to the calculation structure (additive or multiplicative) and the inclusion of additional factors to account for specific local conditions.

The $\mathrm{P}$ index has been widely employed in many regions of Canada, Europe (Sharpley et al., 2012), and by 47 states of the USA to estimate the risk of P loss from agricultural areas to surface waters (Berzina; Sudars, 2010). However, there are still few studies on the $\mathrm{P}$ index in Brazil. The P index was used by Lopes et al. (2007) in order to model P loss risk in a $52.48 \mathrm{~km}^{2}$ catchment, while Oliveira et al. (2010) analyzed four $P$ index versions using erosion plot data. Both studies were carried out in southern Brazil. However, the southeastern region of the country also faces serious problems resulting from the conversion of natural ecosystems into agricultural ones, such as nutrient losses by erosion and the contamination of streams and water reservoirs (Taffarello et al., 2016). Hence, a useful assessment tool, such as the P index, still needs to be tested for such conditions.

The Brazilian Payment for Environmental Services (PES) program has been looking for tools to assist in a more sustainable rural development and $\mathrm{P}$ index can be a useful assessment tool in this program. The PSE was developed by the Brazilian National Water Agency (ANA) to foster the adoption of forest restoration and soil conservation, in order to improve ecosystem services related to soil and water (Richards et al., 2015). Financial incentives are given to landowners who make adjustments in their farms in order to meet environmental requirements. ANA has also created the Water Producer Program and the Water Conservation Program, which were developed in order to protect the headwater catchments of the Cantareira System: a very large set of water reservoirs and catchments that provide water to more than 10 million people in the City of São Paulo (Pereira et al., 2010). In the Posses catchment, the Water Producer Program is developing a protocol to be applied elsewhere in Brazil to estimate environmental benefits and setting financial awards for complying landowners (Guedes; Seehusen, 2011; Jardim; Bursztyn, 2015). In such context, models can be of valuable aid in order to understand and to simulate the effects of land use changes and support practices on soil and water quality.

This study aimed 1) to use the $P$ index model to rank the risk of P loss in the Posses catchment; 2) to evaluate the effect of land use changes on P loss risk; and 3) to contribute to discussions on how the $\mathrm{P}$ index model can be employed in the PES program.

\section{MATERIAL AND METHODS}

\section{Study site}

The study was conducted at the Posses catchment, which covers an area of 1,200 ha within the Jaguari River Basin, and is located at the Municipality of Extrema, State of Minas Gerais, Brazil (Figure 1). The Jaguari River is the longest river of the Cantareira System (Pereira et al., 2010). Although heavily deforested, the Posses catchment is located in a very vulnerable biome, the Brazilian Atlantic Rainforest. Posses has a $\mathrm{Cfb}$ climate (humid subtropical with temperate summer and temperatures between 18 and $22{ }^{\circ} \mathrm{C}$ ), according to the Köppen classification and the average annual precipitation of $1,447 \mathrm{~mm}$.

In the Posses catchment, elevations and slopes range from 947 to $1,456 \mathrm{~m}$ and from 0 to $168 \%$ (mean of $27 \%$ ) respectively (Figures $2 \mathrm{~A}$ and $2 \mathrm{~B}$ ). The main soil classes, according to Soil Survey Staff (1999), are Ultisols (Red-Yellow Argisols (PVA), in the Brazilian Soil Classification System (Santos et al., 2013)), Inceptisols (Humic $(\mathrm{CH})$ and Haplic (CX) Cambisols), Entisols (Litholic (RL) and Fluvic (RY) Neosols). Figure 2 displays the digital elevation model (DEM), slope, soil map and soil sampling sites, and land use distribution in the catchment. These maps have a spatial resolution of $30 \mathrm{~m}$, and the DEM was obtained from the Shuttle Radar Topography Mission (SRTM), also with $30 \mathrm{~m}$ spatial resolution. 


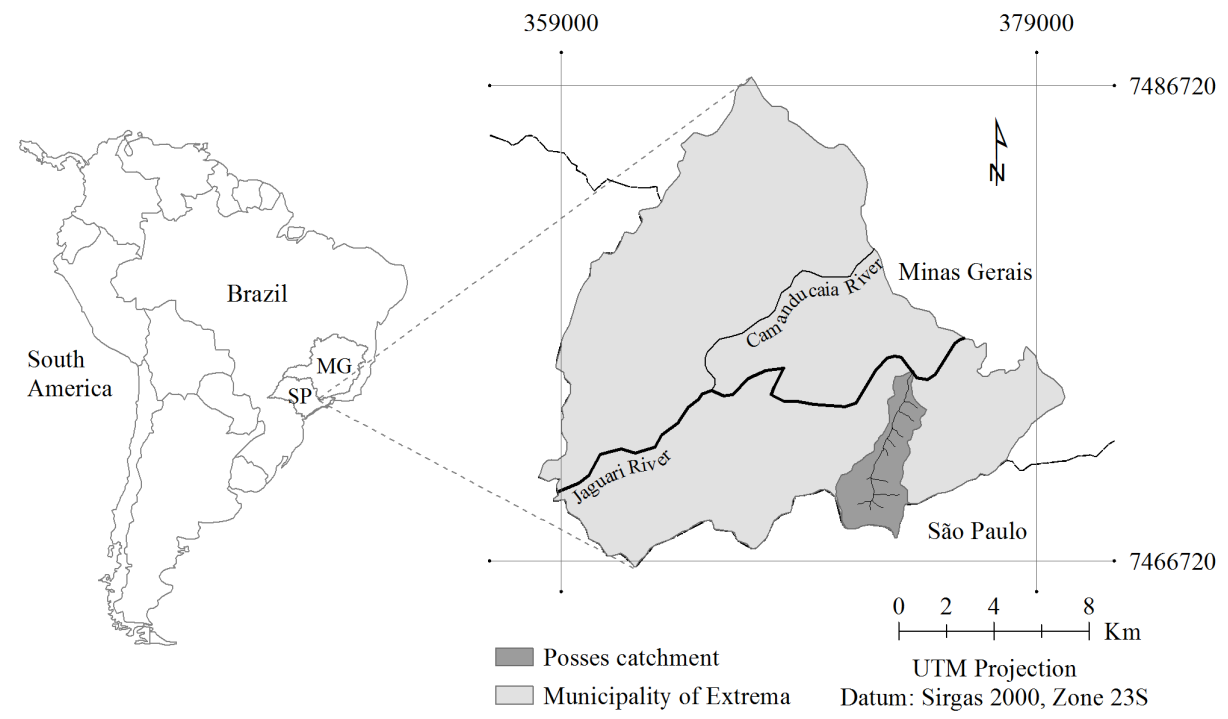

Figure 1: Location of Posses catchment in the Municipality of Extrema, State of Minas Gerais, Brazil.
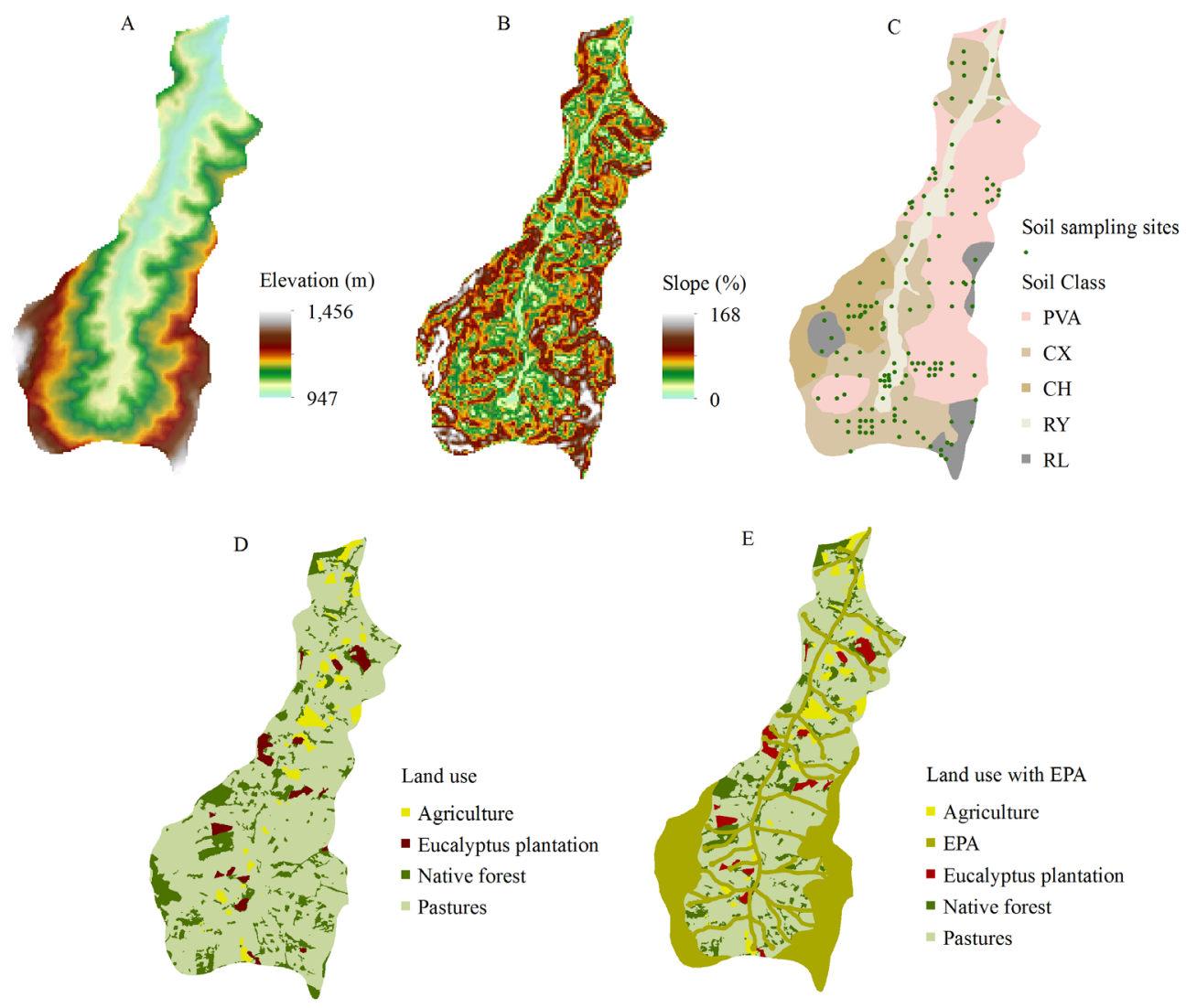

Figure 2: Digital elevation model, slope, soil class and soil sampling sites, land use maps in the Posses catchment and the simulated land use relating to the scenario 2 (see section "Simulations of land-use scenarios in the Posses catchment"). PVA stands for Ultisols (Red-Yellow Argisols), CH for Inceptisol (Humic Cambisols), CX for Inceptisol (Haplic Cambisols), RL for Entisol (Litholic Neosols), and RY for Entisol (Fluvic Neosols). EPA stands for Environmental Protection Areas. 
The catchment is characterized by mixed land use and small farms, as displayed in Figure 2D, which was produced by visual interpretation of a QuickBird satellite image ( $0.60 \mathrm{~m}$ resolution) from 2011 . The main land uses are pastures, eucalyptus plantation, agriculture (maize), and native forest. A great part (78\%) of the catchment, at the moment of the study was occupied by old, degraded pastures; whereas $4 \%$ of the area was under agriculture, $3 \%$ under eucalyptus plantation, and the remaining under native forest.

\section{Framework for $\mathbf{P}$ index}

The $\mathrm{P}$ index is determined according to Equation 1:

$\mathrm{P}$ index $=($ Source factor $*$ Transport factor $*$ Precipitation factor) $/ 4$

Table 1 shows the parameters and data used for the proposed Posses P index, presented in terms of source and transport factors.

Due to low livestock density and low amounts of manure used in the Posses catchment, in comparison to other areas for which the $\mathrm{P}$ index was applied, manure was not included as a source factor for the Posses P index.

A flowchart showing the integration of all the major procedures described above for estimating the $\mathrm{P}$ index is presented in Figure 3.

\section{Source factors}

The spatial distribution of soil test P (P Mehlich-1) was obtained by an interpolated map with $30 \mathrm{~m}$ grid cell resolution, based on 150 soil samples ( 0 to $20 \mathrm{~cm}$ depth) taken in the field (Figure 2B). The interpolation was performed by inverse distance weighting (power value equal to 1). Cross-validation results displayed values of $-0.20 \mathrm{mg} \mathrm{kg}^{-1}$ and $11.35 \mathrm{mg} \mathrm{kg}^{-1}$ for the mean absolute error and the root-mean-squared error, respectively.

Information about fertilizer P rates and application methods was gathered from local farmers. Due to typically high $\mathrm{P}$ absorption on tropical soils, the amount of $\mathrm{P}$ applied must be greater than that removed by plants (Lima et al., 2014). Hence, the P balance was set to 1.2 for sites where the fertilizer $\mathrm{P}$ was applied, that is, in agriculture and eucalyptus plantation areas. No fertilizer $\mathrm{P}$ has been applied on areas under pasture or native forest.

\section{Transport factors}

\section{Erosion modelling}

Soil losses were modelled using the RUSLE (Renard et al., 1991) - the revised version of the Universal Soil Loss Equation (Wischmeier; Smith, 1965, 1978) through GIS software. This approach can be summarized by the following Equation 2:

Table 1: Factors and weightings used for calculation of $P$ index in the Posses catchment, Minas Gerais, Brazil. Suggested weightings refer to the Bechmann, Stalnacke and Kvaerno (2007).

\begin{tabular}{|c|c|}
\hline Factors & Relative Weightings \\
\hline \multicolumn{2}{|l|}{ Source factors } \\
\hline Soil P status & $0.2 \times$ soil test $P\left(\mathrm{mg} \mathrm{kg}^{-1}\right)$ \\
\hline Fertilizer $\mathrm{P}$ rate & P fertilizer $\left(\mathrm{kg} \mathrm{ha}^{-1} \mathrm{yr}^{-1}\right)$ \\
\hline Application method & $\begin{array}{l}0.4 \text { (incorporated following application) and } \\
1.0 \text { (surface applied and not incorporated) }\end{array}$ \\
\hline Fertilizer rating & Fertilizer $\mathrm{P}$ rate $\mathrm{x}$ Application method \\
\hline P balance & $\begin{array}{c}0.8 \text { (P removal }>\mathrm{P} \text { application }), 1.0(\mathrm{P} \text { removal }=\mathrm{P} \text { application }) \text { and } 1.2(\mathrm{P} \\
\text { removal }<\mathrm{P} \text { application })\end{array}$ \\
\hline Source factor & (Soil P status + Fertilizer rating) $\times \mathrm{P}$ balance \\
\hline \multicolumn{2}{|l|}{ Transport factors } \\
\hline Soil erosion & Soil loss (Mg ha-1) \\
\hline Surface runoff & 0 (very low), 2 (low), 4 (medium), 6 (high), 8 (very high) \\
\hline Contributing distance & $0.2(>50 \mathrm{~m})$ and $1.0(<50 \mathrm{~m})$ \\
\hline Modified connectivity & 0.7 (riparian buffer $>5 \mathrm{~m}$ ) and 1.1 (direct connection) \\
\hline Transport factor & (soil erosion + surface runoff) $\mathrm{x}$ contributing distance $\mathrm{x}$ modified connectivity \\
\hline
\end{tabular}




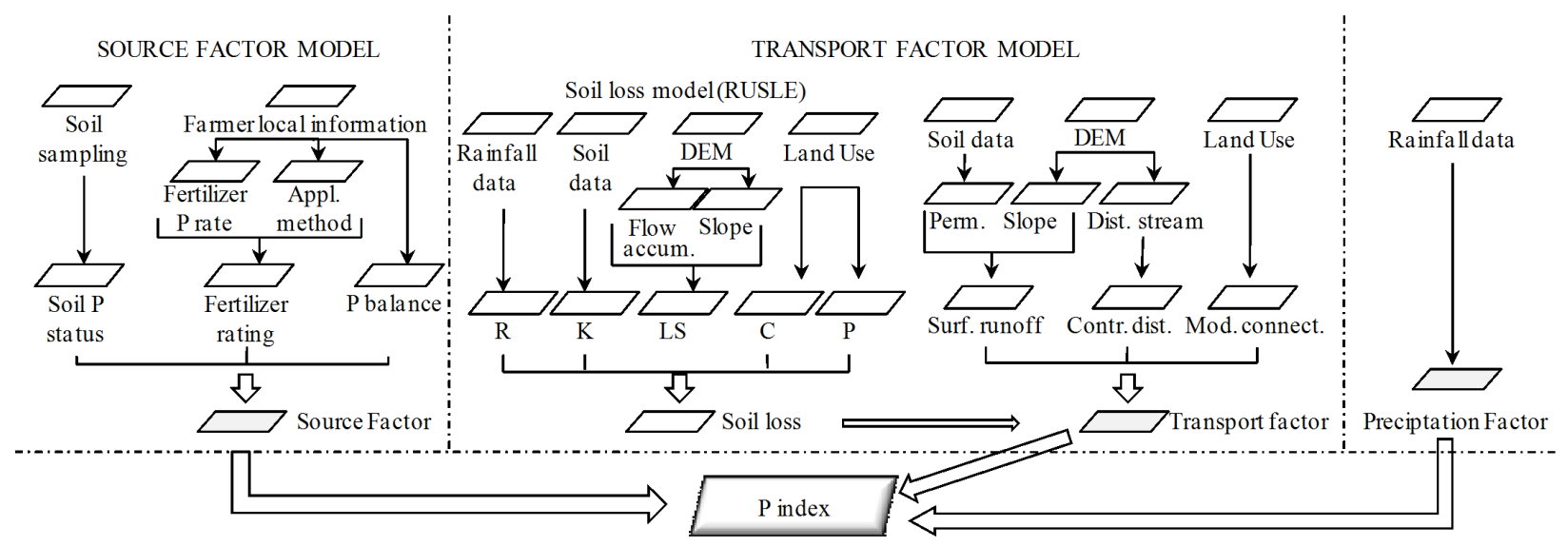

Figure 3: Flowchart of the P index model.

$\mathrm{A}=\mathrm{R} * \mathrm{~K} * \mathrm{LS} * \mathrm{C} * \mathrm{P}$

(2)

where: $\mathrm{A}$ is soil loss $\left(\mathrm{Mg} \mathrm{ha}^{-1} \mathrm{yr}^{-1}\right)$; $\mathrm{R}$ is erosivity factor (MJ $\left.\mathrm{mm} \mathrm{ha}^{-1} \mathrm{~h}^{-1} \mathrm{yr}^{-1}\right)$; $\mathrm{K}$ is erodibility factor $\left(\mathrm{Mg} \mathrm{h} \mathrm{MJ} \mathrm{mm}^{-1}\right)$; LS is topographic factor (dimensionless), representing slope length and steepness, $\mathrm{C}$ is cover-management factor (dimensionless), and $\mathrm{P}$ is support practice factor (dimensionless).

The R-factor value used in this study is 8,213 MJ mm ha-1 $\mathrm{h}^{-1} \mathrm{yr}^{-1}$, which was obtained by Pontes et al. (2015). These authors obtained the $\mathrm{EI}_{30}$ data for the Posses catchment through pluviographic records. The K-factor map was taken from Avalos (2016). Other factors employed to model soil erosion are described in more details below.

\section{Slope-length (L factor)}

The $\mathrm{L}$ factor defines the impact of slope length on soil losses. In this study, the factor was calculated according the concept of the unit-contributing area proposed by Desmet and Govers (1996). Equation 3 was applied to a $30 \mathrm{~m}$ resolution DEM:

$\mathrm{L}_{\mathrm{ij}}=\left[\left(\mathrm{A}_{\mathrm{ij}}+\mathrm{D}_{\mathrm{ij}}^{2}\right)^{\mathrm{m}+1}-\mathrm{A}_{\mathrm{ij}}^{\mathrm{m}+1}\right] /\left[\mathrm{D}^{\mathrm{m}+2}\left(\sin \phi_{\mathrm{ij}}+\cos \phi_{\mathrm{ij}}\right)^{\mathrm{m}}(22.13)^{\mathrm{m}}\right]$

where: $\mathrm{A}_{\mathrm{ij}}\left(\mathrm{m}^{2}\right)$ is the contributing area at the inlet of a grid cell with coordinates $(\mathrm{i}, \mathrm{j})$; D is the grid cell size (m); $\phi$ is the aspect direction for grid cell; and $\mathrm{m}$ is related to the ratio $\beta$ of the rill to interill erosion (Equations 4 and 5).

$\mathrm{m}=\beta /(\beta+1)$

where, $\beta=\left(\sin \theta_{\mathrm{ij}} / 0.0896\right) /\left(0.56+3 *\left(\sin \theta_{\mathrm{ij}}\right)^{0.8}\right.$

\section{Slope-steepness (S factor) factor}

The $\mathrm{S}$ factor measures the effect of slope steepness on soil losses. In this study, the S-factor calculation was performed using a $30 \mathrm{~m}$ DEM and by applying Equation 6, proposed by Wischmeier and Smith (1978):

$\mathrm{S}_{\mathrm{ij}}=65.41 * \sin \theta_{\mathrm{ij}}+4.56 * \sin \theta_{\mathrm{ij}}+0.065$

where: $\theta$ is the gradient of slope in degrees.

All terrain analyses were implemented using the System for Automated Geoscientific Analyses (SAGA).

\section{Cover management factor ( $\mathrm{C}$ factor) and support practice factor ( $P$ factor)}

The cover management factor was based on land use map from Posses catchment. Each land use received a $\mathrm{C}$ factor value according to literature works that were made in regions similar to the studied area (Table 2).

Table 2: Values of cover management factor (C factor) for land uses from Posses catchment, Minas Gerais, Brazil.

\begin{tabular}{ccc}
\hline Land use & C factor & Source \\
\hline $\begin{array}{c}\text { Agriculture } \\
\begin{array}{c}\text { Eucalyptus } \\
\text { plantation }\end{array}\end{array}$ & 0.156 & $\begin{array}{c}\text { De Maria and Lombardi } \\
\text { Neto (1997) }\end{array}$ \\
$\begin{array}{c}\text { Native forest } \\
\text { Pasture }\end{array}$ & 0.015 & Silva et al. (2016) \\
Silva et al. (2016) \\
Dedecek, Resck and Freitas \\
(1986)
\end{tabular}


The $\mathrm{P}$ factor is the ratio between soil losses with a specific support practice and the corresponding losses with upslope and downslope tillage. These practices mostly affect erosion by modifying the flow pattern, grade, or direction of surface runoff and by reducing the amount and rate of runoff (Renard; Foster, 1983). The P factor was set to 1.0 for the entire study area, since no support practices were identified in the catchment.

\section{Surface runoff}

Only overland flow was taken into account as responsible for the transport of $\mathrm{P}$ to the water bodies for the Posses P index because most of Posses soils are oxidic (with high levels of Fe and $\mathrm{Al}$ oxides) and drainage is seldom needed. Also, neither subsurface flow nor groundwater flow were taken into account for Posses P index because of the high capacity of the Posses soils to adsorb $\mathrm{P}$ and avoid its leaching to the major soil depths (Xu; Christodoulatos; Braida, 2006; Elzinga; Sparks, 2007).

The surface runoff classes were based on soil permeability classes and field slope, according to Table 3 . Permeability classes were determined for each soil types in the Posses catchment by Silva et al. (2013), though saturated hydraulic conductivity analysis of undisturbed soil samples using constant head permeameter according to Lima et al. (1990). Slope classes were identified using a $30 \mathrm{~m}$ resolution DEM, which was processed using the Spatial Analyst tool set of ArcGIS 10.1 (ESRI).

\section{Contributing distance and modified connectivity}

Mobilisation and transport of $\mathrm{P}$ can be altered by contributing distance and modified connectivity. Contributing distance is taken as the distance from the edge-of-field to the stream. A limit of $50 \mathrm{~m}$ distance from field to stream was taken because areas greater than 50 $\mathrm{m}$ from the open stream were shown to be less important for nutrient transfer than near-stream sites (Johnes; Heathwaite, 1997).
According to Sharpley, Mcdowell and Kleinman (2001), the risk of causing pollution in the stream can be reduced by vegetated buffers. However, through field description and image classification, no consistent buffer vegetation was detected around the water-bodies at Posses (Figure 2D). Hence, the modified connectivity factor was taken as 1.1 for all areas within the catchment (except in scenario 2, as discussed in section "Simulations of landuse scenarios in the Posses catchment").

\section{Management interpretation}

The $\mathrm{P}$ index can provide a base for improving catchment management. However, the practices utilized to reduce P loss can vary from one site to the next. Some effective measures pointed out by NRCS (2006) were: planting high P-use crops, reducing fertilizer application rates, practicing different application methods (incorporation versus broadcast), and timing (growingseason applications and split-applications).

Also, soil and water conservation practices, such as maintaining crop residues on soil surface, contour planting, terraces construction, reduced tillage and no tillage (Didoné, Minella and Evrard, 2017; Le Gall et al., 2016; Rocha Junior et al., 2017), are used in Brazil to control erosion and nutrient transport. In this sense, a P index classification was performed according to Table 4 (Sharpley; Mcdowell; Kleinman, 2001). On this table are also illustrated some interpretations and recommendations to each $\mathrm{P}$ loss risk class.

\section{Simulations of land-use scenarios in the Posses catchment}

Two scenarios were designed in order to simulate the effect of land use changes on P loss risk in the Posses catchment. Scenario 1 was built in order to identify where the highest $\mathrm{P}$ losses tend to occur if $\mathrm{P}$ fertilizer would be surface applied on pastures. Also, on agriculture and eucalyptus plantation areas were suggested the same $\mathrm{P}$ fertilizer management remarked previously topics.

Table 3: Surface runoff class as a function of soil permeability class and slope (adapted from NRCS, 2006).

\begin{tabular}{cccccc}
\hline \multirow{2}{*}{$\begin{array}{c}\text { Slope } \\
(\%)\end{array}$} & \multicolumn{4}{c}{ Soil Permeability Class } \\
\cline { 2 - 5 } & Very rapid & Moderately rapid and Rapid & Moderate and Moderately slow & Slow & Very slow \\
\hline$<1$ & Negligible & Negligible & Negligible & Low & Low \\
$1-5$ & Negligible & Very low & Low & Medium & High \\
$5-10$ & Very low & Low & Medium & High & Very high \\
$10-20$ & Very low & Low & Medium & High & Very high \\
$>20$ & Low & Medium & High & Very high & Very high \\
\hline
\end{tabular}


Table 4: Phosphorus index management guidance (adapted from Sharpley; Mcdowell; Kleinman, 2001; Weld et al., 2003; NRCS, 2006).

\begin{tabular}{|c|c|c|}
\hline $\mathrm{P}$ index value & $\mathrm{P}$ loss risk class & Interpretations and recommendations \\
\hline$<30$ & Low & $\begin{array}{l}\text { Low potential for } P \text { loss. If current farming practices are maintained, there is a } \\
\text { low risk of adverse impacts on surface waters. }\end{array}$ \\
\hline $30-70$ & Medium & $\begin{array}{l}\text { Medium potential for } P \text { loss. The chance for adverse impacts on surface waters } \\
\text { exists, and remediation measures should be taken to minimise the probability } \\
\text { of } P \text { loss. Use of the } P \text { index to identify specific field areas that could represent } \\
\text { long-term concerns; and conservation practices should be implemented to } \\
\text { lower the probability of future P losses from those areas. }\end{array}$ \\
\hline $70-100$ & High & $\begin{array}{l}\text { High potential for } P \text { loss and adverse impact on surface waters. Soil and water } \\
\text { conservation as well as } \mathrm{P} \text { management measures should be taken to reduce } \\
\text { the risk of } \mathrm{P} \text { movement and water quality degradation. }\end{array}$ \\
\hline$>100$ & Very high & $\begin{array}{l}\text { Very high potential for } P \text { loss and adverse impact on surface waters. Remedial } \\
\text { action should be taken to reduce the risk of P movement. All necessary soil } \\
\text { and water conservation practices and a P-based management plan must be } \\
\text { implemented to minimize P losses. }\end{array}$ \\
\hline
\end{tabular}

Scenario 2 aimed to check the effect of Environmental Protection Areas (EPA) ("Áreas de Conservação Ambiental") proposed by the Water Resources Plan of Extrema municipality (Saad; Silveira, 2013) on P loss risk in farming areas within the Posses catchment. The Posses EPA include buffers of 30 and $50 \mathrm{~m}$ along riparian areas and springs, respectively, and around areas with slopes greater than $100 \%$ or located above $1,100 \mathrm{~m}$ altitude, mandatory under the Brazilian Forest Code. It is worth highlighting that these EPA are set to conserve biodiversity and ecosystem services, and cannot be used for direct economic benefit by landowners (Rodrigues et al., 2011).

Figure 2E displays the spatial distribution of crop, eucalyptus plantation, pasture areas, and EPA in the Posses catchment, suggested on scenario 2. Unlike agriculture, eucalyptus plantation, and pasture areas where the $\mathrm{P}$ fertilizer was suggested according to scenario 1, no $\mathrm{P}$ fertilizer were recommended for native forest and EPA. Additionally, for the modified connectivity a value 0.7 was set because of the buffer along all riparian areas.

\section{Principal component analysis}

Principal component analysis (PCA) was performed to explore the relationships between variables and to identify the principal factors that affected the P-index values for current land use in the Posses catchment. The correlation based PCA was applied to the following variables: contributing distance, surface runoff, soil test $\mathrm{P}, \mathrm{P}$ balance, fertilizer $\mathrm{P}$ rate and soil loss. The $\mathrm{P}$ index was defined as a supplementary variable. The data was standardized to have mean 0 and deviation 1 . The supplementary variable was not used for the components extraction, but was plotted in the biplot graphic for visual interpretation.

\section{RESULTS AND DISCUSSION}

\section{Erosion modelling}

Figure 4 displays the maps of LS and C factor and of soil losses for Posses catchment. The average soil loss was $29 \mathrm{Mg} \mathrm{ha}^{-1} \mathrm{yr}^{-1}$ and few areas had erosion rates $>50$ $\mathrm{Mg} \mathrm{ha}^{-1} \mathrm{yr}^{-1}$ (Figure 4C). These highest soil loss values are related to intensive land use, such as croplands and eucalypt (Table 5). The lowest values were found in the areas closest to the stream channel. In addition to (or because of) the tendency of lowlands to receive sediments from uplands the near stream areas are flatter, RUSLE predicted low erosion rates (Figure 2A and 2B).

In this study, it was assumed a single $\mathrm{R}$ factor and that no erosion control practices were implemented to mitigate soil losses. Thus, despite the $\mathrm{K}$ factor influencing soil losses, the variation of the erosion process was more associated to the LS and C factors (Figure 4A and 3B). The greatest erosion rates were located over the agriculture and eucalyptus plantation (Figures $4 \mathrm{C}$ and Table 5). The erosion rates on pasture areas were also high, but the $\mathrm{C}$ factor value used for such land use might not be able to reflect the spatial variation of this parameter and can be a source of uncertainty in the model. Additionally, the lowest erosion rates for native forest highlight the protection offered by forests against erosion process, once $75 \%$ of this land use is on slopes steeper than $20 \%$. 

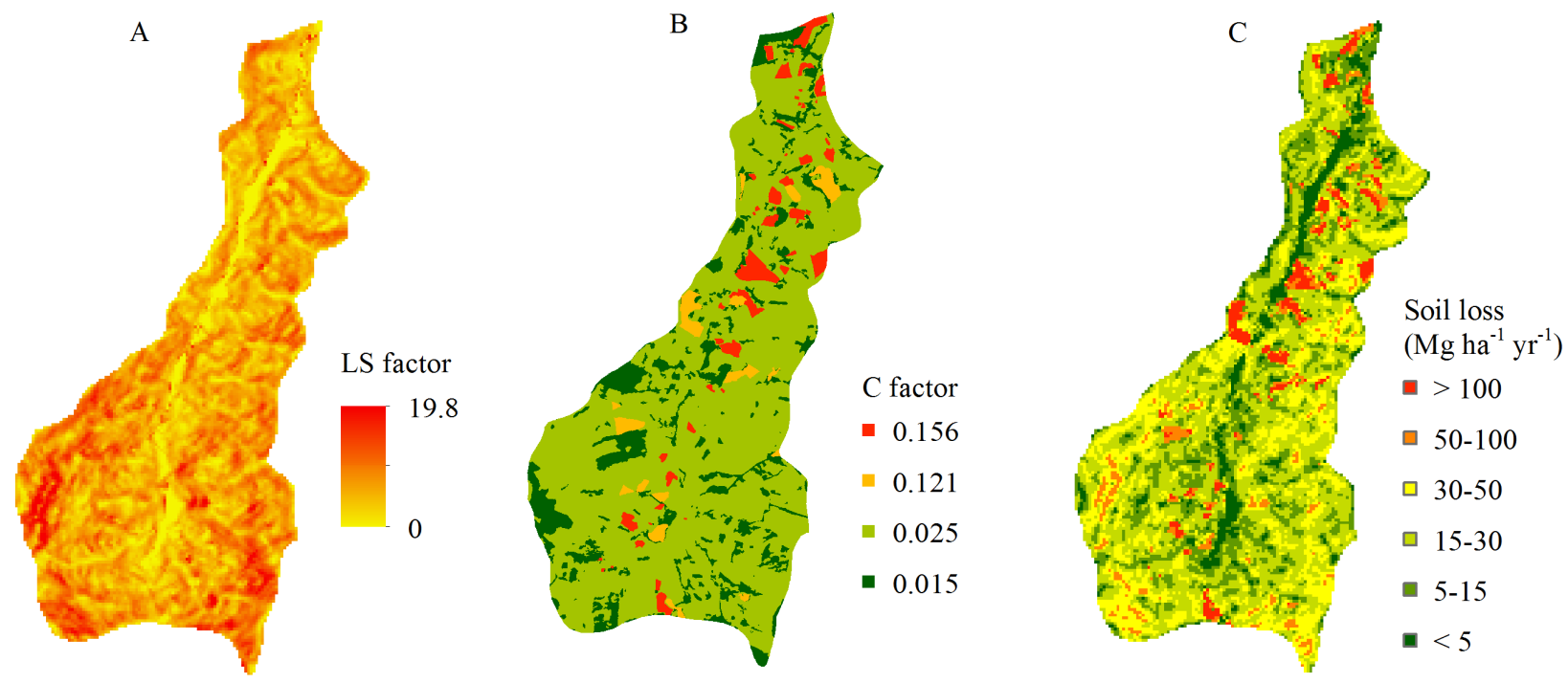

Figure 4: Maps of L-factor, S-factor, C-factor and soil loss for Posses catchment.

Table 5: Average P index factors for each land use within the Posses catchment.

\begin{tabular}{|c|c|c|c|c|}
\hline \multirow{2}{*}{ Site characteristics } & \multicolumn{4}{|c|}{ Land use } \\
\hline & Agriculture & Eucalyptus plantation & Native forest & Pasture \\
\hline \multicolumn{5}{|l|}{ Source factors } \\
\hline Soil test $\mathrm{P}\left(\mathrm{mg} \mathrm{kg}^{-1}\right)$ & $5.5 \pm 4.2$ & $8.2 \pm 5.0$ & $5.8 \pm 4.0$ & $6.5 \pm 4.9$ \\
\hline Fertilizer $\mathrm{P}$ rate $\left(\mathrm{kg} \mathrm{ha}^{-1}\right)$ & $42.4 \pm 4.7$ & $21.5 \pm 4.3$ & 0.0 & 0.0 \\
\hline Fertilizer application method ${ }^{1}$ & 0.4 & 0.4 & - & - \\
\hline P balance factor ${ }^{1}$ & 1.2 & 1.2 & - & - \\
\hline Source factor ${ }^{1}$ & $21.6 \pm 1.5$ & $12.3 \pm 2.1$ & $1.2 \pm 0.8$ & $1.3 \pm 1.0$ \\
\hline \multicolumn{5}{|l|}{ Transport factors } \\
\hline Soil loss (Mg ha-1 $\left.\mathrm{yr}^{-1}\right)$ & $114.9 \pm 50.9$ & $103.8 \pm 59.7$ & $17.0 \pm 10.0$ & $23.5 \pm 12.6$ \\
\hline Surface runoff ${ }^{1}$ & $4.6 \pm 1.7$ & $4.5 \pm 1.7$ & $4.9 \pm 1.7$ & $5.0 \pm 1.8$ \\
\hline Contributing distance $^{1}$ & 0.2 & 0.2 & 0.2 & 0.2 \\
\hline Modified connectivity ${ }^{1}$ & 1.1 & 1.1 & 1.1 & 1.1 \\
\hline Transport factor $^{1}$ & $27.8 \pm 17.1$ & $24.2 \pm 14.5$ & $5.6 \pm 3.8$ & $7.2 \pm 5.4$ \\
\hline
\end{tabular}

'Dimensionless.

\section{Source factor}

Soil test $\mathrm{P}$ values ranged from 1.3 to $58.5 \mathrm{mg} \mathrm{kg}^{-1}$ with mean value of $6.4 \pm 4.8 \mathrm{mg} \mathrm{kg}^{-1}$ over the Posses catchment (Figure 5A). Figure 4A displays the highest soil test $\mathrm{P}$ concentrations near stream areas at the lower tract of the catchment. These areas are deposition sites for upland eroded sediments, and the enrichment of $\mathrm{P}$ by erosion could explain the higher $\mathrm{P}$ content near the stream areas.
Phosphorus test values ranged from 3.3 to $26.5 \mathrm{mg}$ $\mathrm{kg}^{-1}$ over the eucalyptus plantation areas. High values could be due to fertilizer applied, such as the mineralization of $\mathrm{P}$ from eucalyptus organic matter. In pasture and native forest areas, it was found soil test $\mathrm{P}$ values ranged from 1.3 to $58.5 \mathrm{mg} \mathrm{kg}^{-1}$ and 1.7 to $33.6 \mathrm{mg} \mathrm{kg}^{-1}$, respectively. Unlike expected, soil test $\mathrm{P}$ average from pasture was higher than native forest areas (Table 5). The variability of landscape position and soil classes within a single land use can be an 

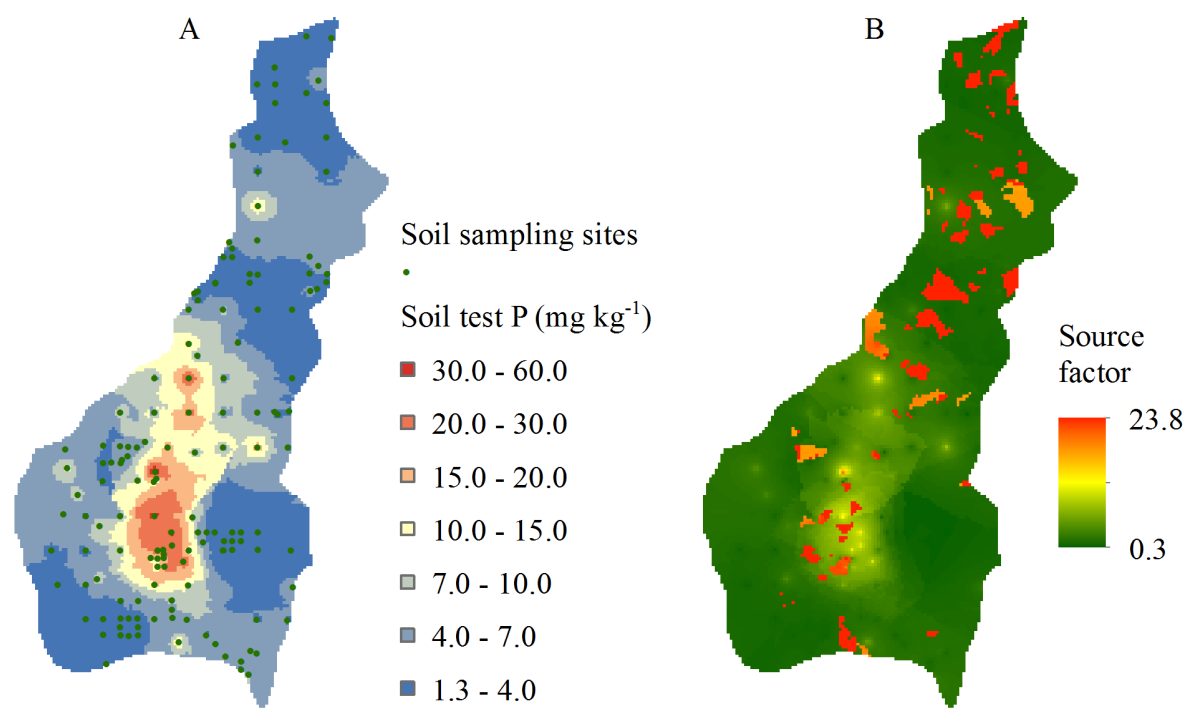

Figure 5: Maps of soil test $\mathrm{P}$ and source factor for Posses catchment.

explanation for wide range of observed $\mathrm{P}$ test values and are reflected in the high standard deviations around the average for specific land uses (Table 5).

Soil $\mathrm{P}$ ranged from 1.6 to $27.3 \mathrm{mg} \mathrm{kg}^{-1}$ over the agricultural areas. Despite the highest amount of $\mathrm{P}$ fertilizer applied on agricultural areas, they also presented the lowest soil P (Table 5). These lowest P levels could be due to the soil tillage practices employed by small farmers in the agricultural areas. These practices usually break soil aggregates, increasing particle surface area and, consequently, $\mathrm{P}$ adsorption. Smaller aggregates are preferentially transported by overland flow, which might contribute to the depletion of soil nutrients by erosion in such context. Moreover, plant uptake on croplands may contribute to further decreasing soil $\mathrm{P}$ at the time of the analysis, in comparison to other land uses.

The P source factor presented in Figure 5B and Table 5 suggested that not only agriculture and eucalyptus plantation but also the near stream areas should be carefully monitored to prevent high P losses. Protection practices and restoration of buffer areas along the riparian zones and springs can be options to reduce off-site erosion impacts at the Posses catchment. In addition to these practices, the management of fertilizer $\mathrm{P}$ also can be an option to reduce the risk of $\mathrm{P}$ loss to the water courses.

\section{Transport factor}

Figure 6A illustrates that most areas $(89.8 \%)$ were classified as having medium to very high risk of surface runoff while the remaining were classified as having low to very low risk. The risk varied with soil class, and the highest values were obtained for RL, RY and CX (Figures 2 and 6A). On the near-stream areas the transport factor was strongly influenced by the surface runoff while on fields located far away from the streams the variations in the transport factor depended more on the erosion rates (Figures 4C, 6A and 6B). This emphasizes the effect of surface runoff from the near-stream areas and reinforces the importance of adding the surface runoff factor in the $P$ index model. Even though soil erosion and surface runoff have been important to the $\mathrm{P}$ losses, other factors such as contributing distance and modified connectivity are also important (Table 5).

$\mathrm{P}$ transport factor reached a maximum value of 212.0 with mean value of 8.4 over the Posses catchment (Figure 6B). In relation to land use, the highest transport factor values were found in agriculture and eucalyptus plantation areas while the lowest values were found in native forest areas (Table 5). Such values depict the influence of land use on the P index model outputs. According to these results, support practices on agriculture and eucalyptus plantation areas are important in order to secure environmental quality.

\section{$P$ index for current land use}

Spatial distribution of the relative risk of $\mathrm{P}$ loss $(\mathrm{P}$ index) for the Posses catchment is illustrated in Figure 7. Almost the whole catchment area (91.4\%) was classified as having low $\mathrm{P}$ loss risk. The explanation for this is that most 
of the catchment area is under pasture (Figure 2D), managed without fertilizer addition, in soils that are naturally poor in $\mathrm{P}$ (Figure 5A), and with high capacity to adsorb P (mainly the PVA and CX - Figure 2C). Several authors highlight the low availability of $\mathrm{P}$ in tropical soils, as well as the high adsorption capacity of Fe and $\mathrm{Al}$ oxides (Fink et al., 2014; Pozza et al., 2007; Ribeiro et al., 2011).

Medium and high $\mathrm{P}$ loss risk areas were largely concentrated in near-stream zones (Figure 7). These sites receive and store $\mathrm{P}$-enriched sediments from eroded uplands, which contributed to increase the P source
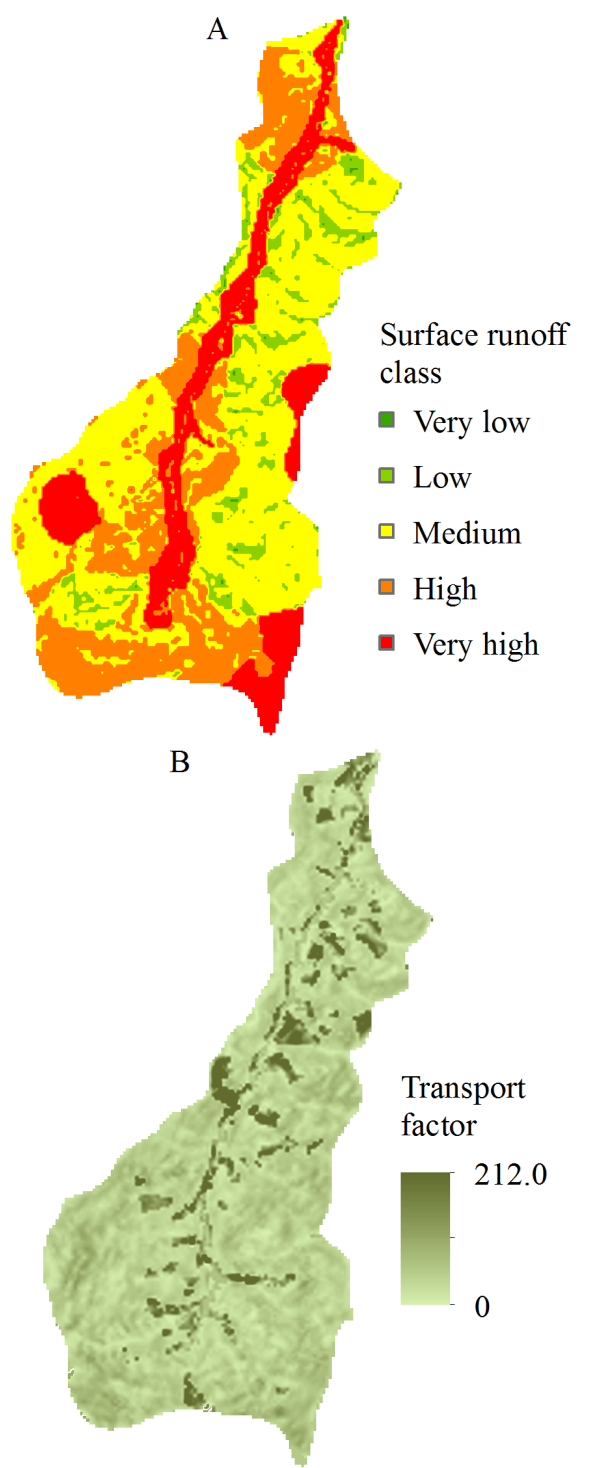

Figure 6: Maps of surface runoff and transport factor for Posses catchment. factor values. Also, although near stream zones are less susceptible to erosion processes, others factors, such as the surface runoff and connectivity to stream, can contribute to the transport of $\mathrm{P}$ stored in these sites, which also helps to explain the highest $\mathrm{P}$ index value for these areas.

The very high $\mathrm{P}$ index values were found mainly at agriculture and eucalyptus plantation areas due to the highest source and transport risks (Table 5 and Figure 7). These results may also reflect both the excessive soil tillage that is carried out downslope and the absence of soil conservation practices by landowners, as observed by Lopes et al. (2007). Thus, better management practices can be focused on these fields. Furthermore, Bechmann, Stalnacke and Kvaerno (2007) pointed out that the P index limit above which special targeted measures must be implemented depends on the water quality improvements to be established. These approaches can assist the decisions about what and where additional measures of management or monitoring the land use within a catchment should be performed. In such context, further knowledge about how variables affect the $\mathrm{P}$ index outputs in specific situations is desirable.

The relationships between the principal variables associated with the $\mathrm{P}$ index for the Posses catchment are illustrated by Figure 8 . The first three principal components (PC) explained up to $81.78 \%$ of the total data variability (Table 6). Although $\mathrm{PC}_{3}$ has been relevant in discriminating the contributing distance factor, most of percentage in accumulated variance was explained by the first component $(44.36 \%)$.

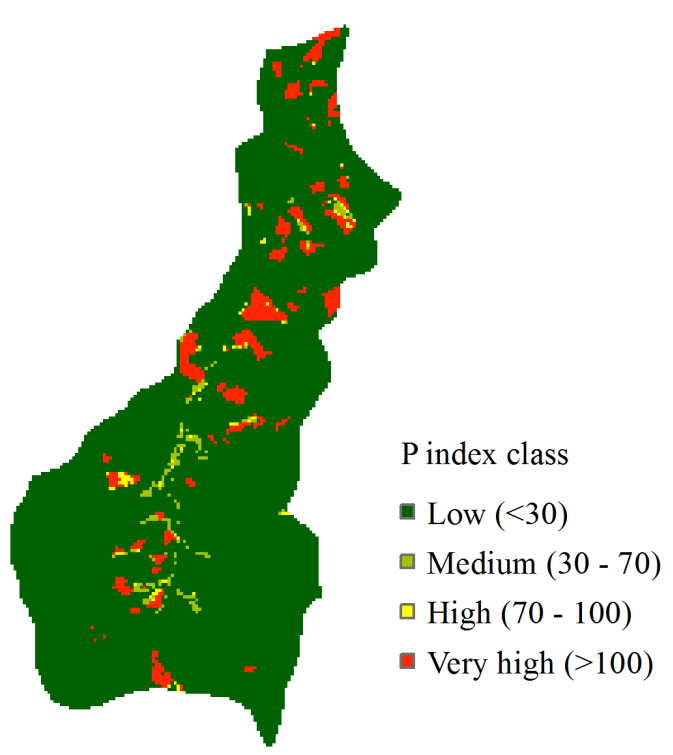

Figure 7: The $\mathrm{P}$ index map for Posses catchment. 


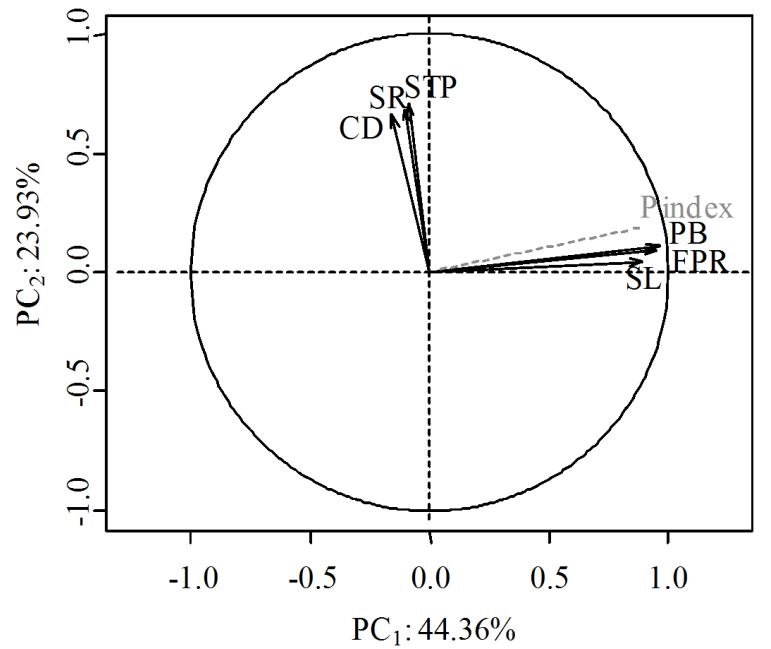

Figure 8: Spatial projection of the eigenvectors of the variables in the first two principal components (PC) for the Posses catchment. CD: contributing distance; SR: surface runoff; STP: soil test P; PB: P balance; FPR: fertilizer P rate; SL: soil loss.

The graphical translation of the high correlation between $\mathrm{P}$ balance, fertilizer $\mathrm{P}$ rate, soil loss and $\mathrm{P}$ index can be visualized in Figure 8. Such correlation illustrates the great influence of the soil loss factor on the P index values, especially on fields located far away from the streams. Also, it highlights the importance of the judicious use of fertilizers in the entire catchment, which was expressed by the high correlation between $\mathrm{P}$ balance and fertilizer $\mathrm{P}$ rate variables with the $\mathrm{P}$ index. The amount of the applied fertilizer $\mathrm{P}$ was also highlighted by Oliveira et al. (2010) as one of the most important factors influencing the values of $\mathrm{P}$ index. The other variables were more correlated with each other and with $\mathrm{CP}_{2}$, which demonstrates that the importance of the surface runoff on $\mathrm{P}$ index is higher in near stream areas, where the values of contributing distance and soil test $P$ were also high. Also, these results showed that in addition to the three factors (soil loss, distance to streams and soil test P) used by Lopes et al. (2007) in the calculation of $\mathrm{P}$ index, the additional variables used in this study are relevant in the Posses catchment.

These findings present important insight into the implications of P index approach as a watershed management tool. Moreover, this model can substantially improve our comprehension of how highland management contributes with P loads to downstream areas. Also, as $\mathrm{P}$ index is a semi-empirical model, further researches are still needed to verify whether the weights for each factor used are ideal to the Posses conditions. However, the principal component analysis provides information about what factors (or variables) should be better managed according to the stream water distance to avoid the P losses in the Posses catchment.

Table 6: Principal component analysis for the first six principal components (PC) considering variables associated to the P loss risk in the Posses catchment.

\begin{tabular}{ccccccc}
\hline Principal components & $\mathrm{PC}_{1}$ & $\mathrm{PC}_{2}$ & $\mathrm{PC}_{3}$ & $\mathrm{PC}_{4}$ & $\mathrm{PC}_{5}$ & $\mathrm{PC}_{6}$ \\
\hline Eigenvalues & 2.66 & 1.44 & 0.81 & 0.76 & 0.28 & 0.05 \\
Total variance (\%) & 44.36 & 23.93 & 13.49 & 12.70 & 4.67 & 0.85 \\
Cumulative variance (\%) & 44.36 & 68.29 & 81.78 & 94.48 & 99.15 & 100.00 \\
& \multicolumn{2}{c}{ Factor coordinates of the variables } & & & \\
CD & $\mathrm{PC1}$ & $\mathrm{PC2}$ & $\mathrm{PC3}$ & & & \\
SR & -0.159 & 0.663 & 0.649 & & & \\
STP & -0.103 & 0.687 & -0.592 & & & \\
PB & -0.086 & 0.708 & -0.048 & & & \\
FPR & 0.962 & 0.113 & 0.080 & & & \\
SL & 0.952 & 0.091 & 0.094 & & & \\
Pindex* & 0.887 & 0.047 & -0.145 & & & \\
\end{tabular}

*Supplementary variable. CD: contributing distance; SR: surface runoff; STP: soil test P; PB: P balance; FPR: fertilizer P rate; SL: soil loss. 


\section{P index for simulated scenarios}

Although pasture areas in the current scenario had low risk of $\mathrm{P}$ loss, changes in land use may to occur. The improvement of the nutritional status of the pastures through fertilization may be one of these changes. Figure 9A displays how the $\mathrm{P}$ index responds to pasture fertilization.

In scenario 1, the P loss risk for areas under pasture fell into the low (15.1\%), medium (45.5\%), high (27.1\%) and very high (12.3\%) categories (Figures 9A and 9D). These results further clarify how pasture areas can become potential $\mathrm{P}$ loss risk sites if fertilizer $\mathrm{P}$ is applied on these areas without additional soil conservation practices.

Although the recovery of degraded pastures is environmentally interesting because it avoids deforestation for pasture formation and because pastures are suitable for the soils in the Posses catchment (Lima et al., 2013a; Silva et al., 2013), great care must be taken when using $P$ fertilizers in this process. Due to phosphorus being essential to plant growth and highly adsorbed by Brazilian soils, forming low solubility compounds, this element is usually applied in an amount greater than required by plants (Lima et al., 2014). This fact further heightens the importance of soil conservation practices in order to avoid water contamination due to deposition of P-enriched sediments.
In addition to $\mathrm{P}$ fertilization, another land use change being encouraged is the incorporation of areas intended for Environmental Protection Areas, referred to in this study as scenario 2 . These areas include the vegetated buffers which are accounted for in the Norwegian P index by adding a modified connectivity variable in the transport factor of 0.7 . This scenario decreased the risk of $\mathrm{P}$ losses in $37.6 \%$ of the catchment area in comparison to the scenario 1 (Figures 9A, 9B and 9C). The highest decreases were predicted for high and very high $\mathrm{P}$ index classes in pasture areas; and for very high $\mathrm{P}$ index class in eucalyptus plantation areas (Figure 9D). These results confirm that the EPA may help the environmental quality and concordats with Lima et al. (2013b) and Silva et al. (2013), who mentioned that the maintenance of vegetation cover can reduce surface runoff and soil erosion, which consequently will reduce the $\mathrm{P}$ index in the Posses catchment. In addition, according to Lima et al. (2013b), the use of vegetative and mechanical practices of soil conservation should also be carried out in this catchment. However, the effect of different soil and water conservation techniques on $\mathrm{P}$ losses is an issue that needs to be explored further in the catchment.
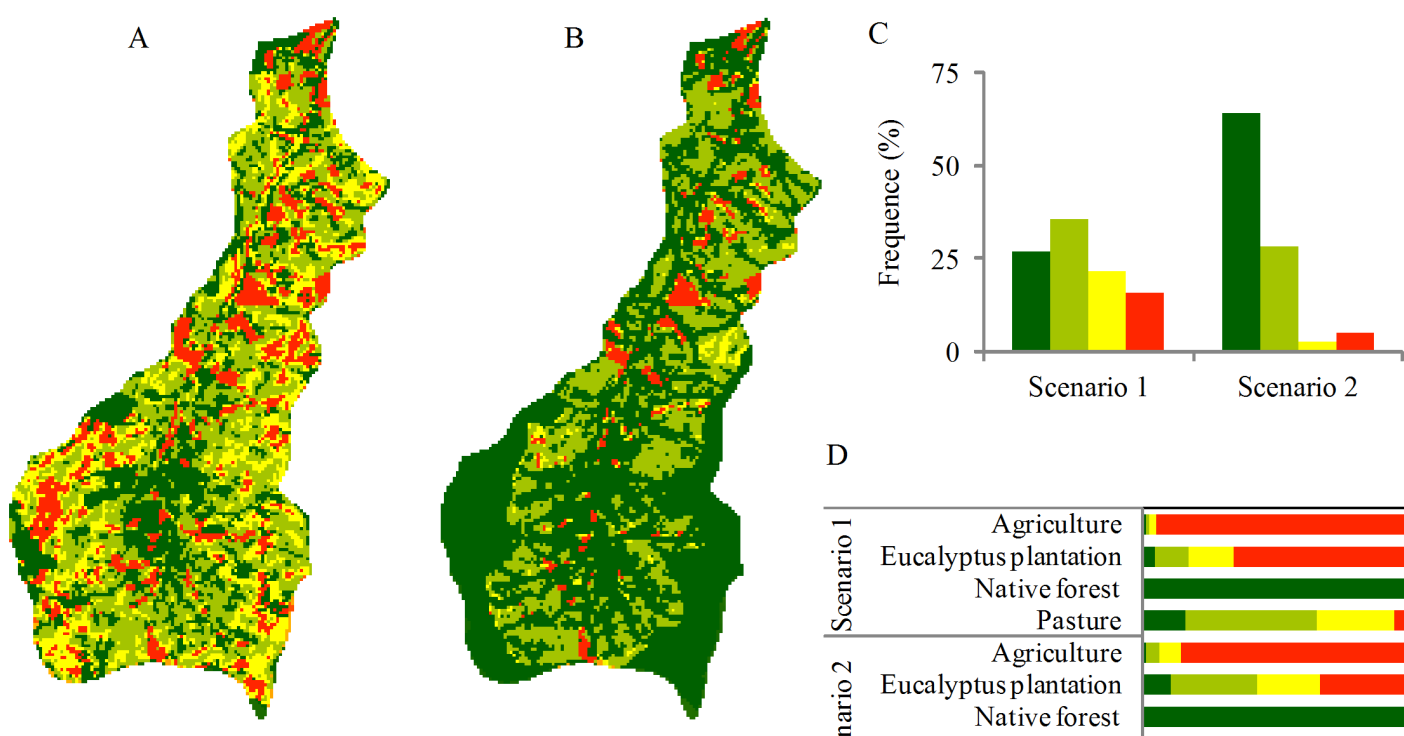

D

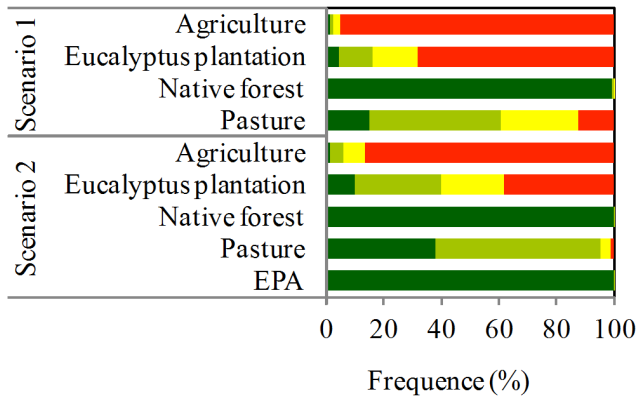

Figure 9: $P$ index maps for scenario $1(A)$ and scenario 2 (B), distribution of $P$ index classes into each scenario (C) and average values of $P$ index for land uses (D) at Posses catchment. 
The $\mathrm{P}$ index has a great potential to be employed by the soil and water conservation programs as a tool for planning and monitoring land use in catchments. However, this model can be improved through additional studies to make it applicable also to other Brazilians catchments.

\section{CONCLUSIONS}

The $\mathrm{P}$ index model identified agriculture and eucalyptus plantation areas as being very high $\mathrm{P}$ loss risk sites at the Posses catchment. The model depicted that reforestation of Environmental Protection Areas can decrease $\mathrm{P}$ loss risk in the case of using of $\mathrm{P}$ fertilizer in pasture areas. The $\mathrm{P}$ index model is a potential support tool to promote judicious use of fertilizers and conservation practices at the Posses catchment.

\section{ACKNOWLEDGEMENTS}

This work was supported by CAPES; CNPq [305010/2013-1 and 471522/2012-0 processes]; FAPEMIG [PPM00422-13, CAGAPQ01423-11 and CAGAPQ01053-15 processes]; and the Extrema City administration.

\section{REFERENCES}

ARNOLD, J. G. et al. Large area hydrologic modeling and assessment part I: Model development. Journal of the American Water Resources Association, 34(1):73-89, 1998.

AVALOS, F. A. P. Variabilidade espacial da erodibilidade do solo e relações com a paisagem na sub-bacia das Posses, Extrema - MG. Lavras, MG, 2016. Available in: <http://repositorio.ufla.br/handle/1/11516>. Access in: August, 13, 2016.

BEASLEY, D. B.; HUGGINS, L. F.; MONKE, E. J. ANSWERS: A model for watershed planning. Transactions of the American Society of Agricultural Engineers, 23(4):938-944, 1980.

BECHMANN, M. E.; STALNACKE, P.; KVAERNO, S. H. Testing the Norwegian phosphorus index at the field and subcatchment scale. Agriculture, Ecosystems and Environment, 120(2):117-128, 2007.

BERZINA, L.; SUDARS, R. The concept of phosphorus index for identification of phosphorus loss risk, I-The literature Review. Latvijas Lauksaimnieci- ${ }^{-}$bas Universita ${ }^{-}$teRaksti, 25(1):12-19, 2010.

BUCHANAN, B. P. et al. A phosphorus index that combines critical source areas and transport pathways using a travel time approach. Journal of Hydrology, 486(1):123-135, 2013.
CAMPBELL, J. M.; JORDAN, P.; ARNSCHEIDT, J. Using highresolution phosphorus data to investigate mitigation measures in headwater river catchments. Hydrology and Earth System Sciences, 19(1):453-464, 2015.

CELA, S. et al. Nutrient management planners' feedback on New York and Pennsylvania phosphorus indices. Journal of Soil and Water Conservation, 71(4):281-288, 2016.

COLLINS, A. L.; STUTTER, M.; KRONVANG, B. Mitigating diffuse pollution from agriculture: International approaches and experience. Science of The Total Environment, 468469(6):1173-1177, 2014.

DE MARIA, I. C.; LOMBARDI NETO, F. Razão de perdas de solo e facor C para sistemas de manejo da cultura do milho. Revista Brasileira de Ciência do Solo, 21(2):263-270, 1997.

DECHEN, S. C. F. et al. Perdas e custos associados à erosão hídrica em função de taxas de cobertura do solo. Bragantia, 74(2):224-233, 2015.

DEDECEK, R. A.; RESCK, D. V. S.; FREITAS, E. Perdas de solo, água e nutrients por erosão em Latossolo Vermelho-Escuro dos cerrados em diferentes cultivos sob chuva natural. Revista Brasileira de Ciência do Solo, 10(3):265-272, 1986.

DESMET, P. J. J.; GOVERS, G. A GIS procedure for automatically calculating the USLE LS factor on topographically complex landscape units. Journal of Soil and Water Conservation, 51(5):427-433, 1996.

DIDONÉ, E. J.; MINELLA, J. P. G.; EVRARD, O. Measuring and modelling soil erosion and sediment yields in a large cultivated catchment under no-till of Southern Brazil. Soil and Tillage Research, 174(1):24-33, 2017.

EGHBALL, B.; GILLEY, J. E. Phosphorus risk assessment index evaluation using runoff measurements. Journal of Soil and Water Conservation, 56(3):202-206, 2001.

ELZINGA, E. J.; SPARKS, D. L. Phosphate adsorption onto hematite: An in situ ATR-FTIR investigation of the effects of $\mathrm{pH}$ and loading level on the mode of phosphate surface complexation. Journal of Colloid and Interface Science, 308(1):53-70, 2007.

FINK, J. R. et al. Mineralogy and phosphorus adsorption in soils of south and central-west Brazil under conventional and no-tillage systems. Acta Scientiarum, 36(3):379-387, 2014.

GATIBONI, L. C. et al. Soil phosphorus thresholds in evaluating risk of environmental transfer to surface waters in Santa Catarina, Brazil. Revista Brasileira de Ciência do Solo, 39(4):1225-1234, 2015. 
GOLLAMUDI, A.; MADRAMOOTOO, C. A.; ENRIGHT, P. Water quality modeling of two agricultural fields in southern Quebec using SWAT. Transactions of the American Society of Agricultural and Biological Engineers, 50(6):1973-1980, 2007.

GUEDES, F. M.; SEEHUSEN, S. E. Pagamento por serviços ambientais na Mata Atlântica: Lições aprendidas e desafios. Brasília, DF: Ministério do Meio Ambiente, 2011. $272 p$.

JARDIM, M. H.; BURSZTYN, M. A. Pagamento por serviços ambientais na gestão de recursos hídricos: O caso de Extrema (MG). Engenharia Sanitária e Ambiental 20(3):353-360, 2015.

JOHNES, P. J.; HEATHWAITE, A. L. Modelling the impact on water quality of land use change in agricultural catchments. Hydrological Processes, 11(3):269-286, 1997.

KETTERINGS, Q. M. et al. Restructuring the P Index to better address $P$ management in New York. Journal of Environment Quality, 42(5):1-8, 2017.

LE GALL, M. et al. Tracing sediment sources in a subtropical agricultural catchment of Southern Brazil cultivated with conventional and conservation farming practices. Land Degradation \& Development, 28(4):1426-1436, 2016.

LEMUNYON, J. L.; GILBERT, R. G. The concept and need for a phosphorus assessment tool. Journal of Production Agriculture, 6(4):483-486, 1993.

LIMA, G. C. et al. Avaliação da cobertura vegetal pelo índice de vegetação por diferença normalizada (IVDN). Revista Ambiente \& Água, 8(2):204-214, $2013 a$.

LIMA, G. C. et al. Estimativa do potencial de recarga na SubBacia das Posses, Extrema (MG) em função dos atributos fisiográficos, pedológicos e topográficos. Geociências, 32(1):51-62, 2013b.

LIMA, G. C. et al. Variabilidade de atributos do solo sob pastagens e mata atlântica na escala de microbacia hidrográfica. Revista Brasileira de Engenharia Agrícola e Ambiental, 18(5):517-526, 2014.

LIMA, J. M. et al. Dispersão do material de solo em água para avaliação indireta da erodivilidade de Latossolos. Revista Brasileira de Ciência do Solo, 14(1):85-90, 1990.

LOPES, F. et al. Utilização de P-Index em uma bacia hidrográfica através de técnicas de geoprocessamento. Revista Brasileira de Engenharia Agrícola e Ambiental, 11(3):312-317, 2007
LOU, H. et al. Detecting and analyzing soil phosphorus loss associated with critical source areas using a remote sensing approach. Science of The Total Environment, 573(1):397-408, 2016.

MARDAMOOTOO, T.; KWONG, K. F. N. K.; PREEZ, C. C. D. Assessing environmental phosphorus status of soils in Mauritius following long-term phosphorus fertilization of sugarcane. Agricultural Water Management, 117(1):26-32, 2013.

NATURAL RESOURCES CONSERVATION SERVICE - NRCS. Phosphorus index assessment for Montana. 2006. Available in: <https://www.nrcs.usda.gov/wps/portal/nrcs/detail/mt/ technical/ecoscience/agronomy/?cid=nrcs144p2_056561>. Access in: July, 08, 2016.

OCKENDEN, M. C. et al. Keeping agricultural soil out of rivers: Evidence of sediment and nutrient accumulation within field wetlands in the UK. Journal of Environmental Management, 135(1):54-62, 2014.

OLIVEIRA, M. F. M. et al. Estimativa do potencial de perda de fósforo através da metodologia "P Index". Revista Brasileira de Engenharia Agrícola e Ambiental, 14(41):267-273, 2010.

PEREIRA, P. H. et al. Conservador das Águas: 5 Anos. Extrema: Departamento de Meio Ambiente de Extrema, 2010. 68p.

PONTES, L. M. et al. Erosividade das chuvas na Sub-bacia Hidrográfica das Posses, Extrema, MG. Lavras, MG, 2015. Available in: <http://www.sbagro.org.br/index. php?option=com_content\&view=article\&id=104\&ltemid=118>. Access in: July, 02, 2016.

POZZA, A. A. A. et al. Retenção e dessorção competitivas de ânions inorgânicos em gibbsita natural de solo. Pesquisa Agropecuária Brasileira, 42(11):1627-1633, 2007.

RENARD, K. G. et al. RUSLE: Revised Universal Soil Loss Equation. Journal of Soil and Water Conservation, 46(1):30-33, 1991.

RENARD, K. G.; FOSTER, G. R. Soil conservation: Principles of erosion by water. In: DREGNE, H. E.; WILLIANS, W. O. Dryland Agriculture. Madison: American Society of Agronomy, 1983. v.23, p.155-176.

RIBEIRO, B. T. et al. Cargas superficiais da fração argila de solos influenciadas pela vinhaça e fósforo. Química Nova, 34(1):05-10, 2011.

RICHARDS, R. C. et al. Governing a pioneer program on payment for watershed services: Stakeholder involvement, legal frameworks and early lessons from the Atlantic forest of Brazil. Ecosystem Services, 16(1):23-32, 2015. 
ROBERTS, W. M. et al. Assessing the risk of phosphorus transfer to high ecological status rivers: Integration of nutrient management with soil geochemical and hydrological conditions. Science of the Total Environment, 589(1):2535, 2017.

ROCHA JUNIOR, P. R. et al. Soil, water, and nutrient losses from management alternatives for degraded pasture in Brazilian Atlantic Rainforest biome. Science of the Total Environment, 583(1):53-63, 2017.

RODRIGUES, R. R. et al. Large-scale ecological restoration of high-diversity tropical forests in SE Brazil. Forest Ecology and Management, 261(10):1605-1613, 2011.

SAAD, A. M.; SILVEIRA, F. T. Plano municipal de recursos hidricos do municipio de Extrema. 2013. Available in: <http://www.agenciapcj.org.br/novo/component/content/ article/54-projetos/424-extrema-mg>. Access in: October, 22, 2017.

SANTOS, H. G. et al. Sistema brasileiro de classificação de solos. 3.ed. rev. e ampl. Brasília: Embrapa, 2013. 353p.

SCHINDLER, D. W. Evolution of phosphorus limitation in lakes. Science, 195(4275):260-262, 1977.

SHARPLEY, A. et al. Phosphorus Indices: Why we need to take stock of how we are doing. Journal of Environment Quality, 41(6):1711-1719, 2012.

SHARPLEY, A. et al. Phosphorus legacy: Overcoming the effects of past management practices to mitigate future water quality impairment. Journal of Environment Quality, 42(5):1308-1326, 2013.

SHARPLEY, A. N. et al. Development of phosphorus indices for nutrient management planning strategies in the United States. Journal of Soil and Water Conservation, 58(3):137-151, 2003.

SHARPLEY, A. N.; MCDOWELL, R. W.; KLEINMAN, P. J. A. Phosphorus loss from land to water: Integrating agricultural and environmental management. Plant and Soil, 237(2):287-307, 2001.
SILVA, B. P. C. et al. Soil and water losses in eucalyptus plantation and natural forest and determination of the USLE factors at a pilot sub-basin in Rio Grande do Sul, Brazil. Ciência e Agrotecnologia, 40(4):432-442, 2016.

SILVA, M. A. et al. Sistema de informações geográficas no planejamento de uso do solo. Revista Brasileira de Ciências Agrárias, 8(2):316-323, 2013.

SOIL SURVEY STAFF. Soil taxonomy: A basic system of soil classification for making and interpreting soil surveys. 2.ed. Washington: Natural Resources Conservation Service, 1999. 169p.

TAFFARELLO, D. et al. Field investigations of the 2013-14 drought through quali-quantitative freshwater monitoring at the headwaters of the Cantareira System, Brazil. Water International, 41(5):775-800, 2016.

WELD, J. L. The Pennsylvania phosphorus index: Version 1. Pennsylvania: Publications Distribution Center, 2003. 24p.

WILLIAMS, J. R.; JONES, C. A.; DYKE, P. T. A modeling approach to determining the relationship between erosion and soil productivity. Transactions of the American Society of Agricultural Engineers, 27(1):129-144, 1984.

WISCHMEIER, W. H. E.; SMITH, D. D. Predicting rainfall erosion losses from cropland east of the Rocky Mountains. Washington: United States of Department of Agriculture, 1965, 47p.

WISCHMEIER, W. H. E.; SMITH, D. D. Predicting rainfall erosion losses: A guide to conservation planning. Washington: United States Department of Agriculture, 1978. 58p.

XU, N.; CHRISTODOULATOS, C.; BRAIDA, W. Modeling the competitive effect of phosphate, sulfate, silicate, and tungstate anions on the adsorption of molybdate onto goethite. Chemosphere, 64(8):1325-1333, 2006.

ZHOU, B. et al. Land use as an explanatory factor for potential phosphorus loss risk, assessed by $\mathrm{P}$ indices and their governing parameters. Environmental Science: Processes \& Impacts, 17(8):1443-1454, 2015. 